\title{
Class Lines
}

Sophia met Solomon in the military-or a military branch of sorts. It was called the signal corps-electronics and radio, the high tech of the 1940s, where those with more brains than muscles could contribute to the war against fascism. A certain prestige attached to being selected for this special unit, a bit like the "smart camps" for kids with high IQs and computer skills but little interest in sports. He was her supervisor, or rather, the supervisor of a group of women workers contributing to the war effort. They tested equipment before it was sent overseas. To this day, Sophia protests that she thought Solomon was interested in her best friend, who sat to her left on the assembly line. Her friend, a petite, dark, striking woman, had won numerous beauty contests-so many, in fact, that Sophia thought herself ugly and large by comparison. You see, Solomon was only five feet two inches.

Two opposites they were, much like the poles of the complicated electrical systems they worked on. She had a bright complexion-blushing rosy cheeks and thick, light-brown curly hair that she tried to control with tortoise-shell combs. In grade school her teachers demanded that she "wipe that rouge off her face." Of course, she was embarrassed. "But it's natural," she'd protest meekly.

He was dark. Except for penetratingly blue eyes, he had black hair and sallow skin. When he had been in the sun he could 
pass for African American, and he was proud of that fact. It linked him to his childhood in the ghetto and it emphasized his natural sympathy for all humans, "regardless of race, creed, or color." He was fond of this phrase.

She was always moving-practicing modern dance as a young mother, tennis, walking, swimming-active and talkative, positive and upbeat. Her high energy seemed forced at times, as though she had to keep moving until she was exhausted, to avoid slothfulness, her version of laziness, or just thinking too much. For Sophia, actions spoke louder than words. She was never nervous, although she struggled for a sense of power and control that she tried to keep under the surface.

He was contemplative, sedentary, and moody. While he would

The Teacup Ministry and Other Stories talk incessantly in a charming way in his manic phases, he usually preferred to be alone with the newspaper or a good book. In his depressions he slept.

Sophia and Solomon were both the children of Eastern European immigrant parents who came to the United States as poor refugees. They struggled to make ends meet. Her parents owned a mom-and-pop grocery in Brooklyn. They worked long hours, especially Sophia's mother, who was also a domestic wizard: cooking, sewing, she could make anything, even after a hard day's work. When Sophia was a little girl, they'd send her to the bank on the subway with the daily cash deposit tucked into her clothing. A hat pin was her weapon and a hot sweet potato her solace and warmth. Sophia had to fight with her gambler father to go to college. He wanted her to work in the store. Luckily, her hardworking mother supported her higher education at the public, urban university. At the time it was the only coed institution in the City College system. She didn't want to go to Hunter College, which was all girls. (At that time, college girls were called girls, not women.)

Right after Sophia married Solomon, her mother died suddenly at the age of forty-eight. "She worked herself to death." Sophia always spoke of her mother with great admiration and sadness. Not only did she work full time, she also made beautiful clothes for Sophia, cooked and baked like a professional, and fermented her own cherries in a large vat on the fire escape. 
Cherry vishniak, they used to call it. Sophia remembers tasting the deliciously sweet liqueur. The conventional wisdom may have attributed her death to overwork, but, more likely, she suffered a massive stroke or heart attack. They didn't know how to control high blood pressure then.

Solomon's father also died young. Solomon became the caretaker of his Philadelphia family at sixteen, when his father, a wallpaper hanger trained in Europe in classical violin, died of lip cancer. The money set aside for Solomon's medical education went instead for his father's cancer treatments, or so the story goes. They were poor, but cultured. Solomon's mother, Rose, a tiny woman with thinning black hair, was always reading-history, Russian novels, and newspapers in Russian, a language she refused to speak to anyone outside of her generation. Russian was, after all, "un-American." She attributed her near baldness to her long girlhood braids pulling on her scalp. Before 1920, she had worked on the assembly line in the now infamous Triangle Shirtwaist Factory, the one in which so many women workers had been killed in a horrible fire. She didn't like to talk about it, and the term posttraumatic stress had not been invented yet.

In the 1930s, Solomon and his younger brother, Martin, worked their way through college playing summers in their own band in bars in coastal towns and islands off the East Coast, such as Winston, Atlantic City, and towns further northSolomon on piano, Martin on sax and clarinet. Solomon chose to study liberal arts and electronics at the local university, even though he had been accepted to the prestigious Curtis Institute of Music. The hours and whole days of practicing had paid off, but he wanted to branch out and get away from the endless drills and scales. He had also joined the Communist Party, a legacy he inherited from his radical, European father. Martin, who was much more carefree than Solomon, became a hardliving musician-corporate New York music executive by day, big-band sax player by night. His thirties found him still a confirmed bachelor, which in those days equaled a rejection of the institution of marriage. Finally, he married in his early forties, but divorced only ten years later. As a hobby, he wrote trashy 
novels and short stories, which, of course, he did under a pseudonym. Sophia was fond of quoting this fact. Whenever she talked about him, a distinct note of puritanism came into her voice. After work he dressed like a bum, so as not to get mugged on the streets late at night. His torn jackets and raggedy pants were part of a survival strategy, but they did not protect him from the pulmonary embolism that killed him at the age of sixty. Solomon never recovered from the death of Martin. His depressions got longer and deeper; anger often consumed him.

Before he met Sophia, Solomon had been engaged to "a Bryn Mawr girl," diamond engagement ring and all. As a private women's college in the East, Bryn Mawr was noted for its high academic standards, high tuition, and high level of elitism and

The Teacup Ministry and Other Stories snobbery. Sophia often repeated the mythical family story in which Solomon's mother, Rose, prepared an elaborate dinner for his fiancée's family. She polished silver, cooked all of her best dishes, and worried over the house, the food, and the table settings. After all of her efforts, the "Bryn Mawr girl's" family criticized Rose for failing to place the silverware exactly one inch from the edge of the table. Of course her Main Line family disapproved of Solomon's modest beginnings; he knew that in the abstract. Now it became real to him in a most painful way. They didn't care about his musical talents or his high academic standing. His sensitivity and good nature didn't matter to them. Solomon moped and brooded. Then he went off alone to the ocean, where he sat in a motel room for three days. When he came back, he announced the end of his engagement. But she never gave back the expensive ring.

Sophia took some pleasure in telling and retelling this story, especially the parts about the misplaced silverware and the expensive diamond ring. In a peculiar way, Sophia showed jealousy toward the defunct relationship, an odd combination of class competition and emotional warfare. When Sophia was angry at Solomon, she would tell him he should have married his "Bryn Mawr girl."

In the late 1940s, Solomon, his mother, and his brother moved from the slums of North Philadelphia to a row house on the city's periphery. As the oldest son, Solomon became the head of 
the household. He took financial responsibility for his mother and brother. The 13th Street house, as they called it, was spacious, with living room, dining room, and kitchen on the first floor and three bedrooms upstairs. It even had a full basement and garage. Sophia and Solomon lived there for the first seven years of their married life. The misery in Sophia's voice could be heard every time she mentioned 13th Street. "A hole in the wall is better than a palace, if it's yours and yours alone. Never live in someone else's house," she'd repeat over and over again. It became a litany. They later moved to the suburbs.

Just after Solomon died, almost twenty years after Martin's death, Solomon's children received a phone call from the adult child of Frances, Solomon and Martin's half brother, son of their father, Henry, from his first marriage. It seems that Henry's first wife had died giving birth to Frances, who was then adopted by his mother's sister and her husband in California. This explained his different last name and, in part, his absence from the lives of Solomon and Martin. Lauren, Solomon's daughter, had always wondered how her grandfather had lived without seeing his firstborn son for so many years. She never had a chance to ask him, though, since he died before she was born.

Ironically, perhaps, Frances, Solomon, and Martin turned out to be a lot alike. They were all rather bad at business. Solomon and Frances were just too nice and sensitive to be good businessmen. They loved music and were accomplished musicians. With the exception of Martin, whose daughter has been lost to the family with a drug problem connected to a bitter divorce, they produced professional children with nontraditional careers. They each in their own unique way remember where they came from. The children seek links to people who remind them of family class memories.

All three of Frances's children are psychotherapists working with diverse clients in Los Angeles and Phoenix. Solomon's son, Alan, is a public defender, and his daughter, Lauren, is a pediatrician specializing in diseases of children in medically underserved areas-urban communities and third world villages.

Class lines can divide; they can also be connected and realigned if you do not forget where you came from. 
THIS PAGE INTENTIONALLY LEFT BLANK 